\title{
STRATEGI PENGEMBANGAN USAHA AGROINDUSTRI SIRUP PARIJOTO (Medinilla speciosa) DI DESA COLO KECAMATAN DAWE KABUPATEN KUDUS
}

\section{Agroindustry Business Development Strategy of Parijoto Syrup (Medinilla Speciosa) in Colo Village Dawe District Kudus Regency}

\author{
Misbachul Munir ${ }^{1}$, Sri Wahyuningsih ${ }^{2 *}$, Istanto $^{3}$ \\ Program Studi Agribisnis \\ Fakultas Pertanian Universitas Wahid Hasyim Semarang \\ email: wahyuningsih281169@gmail.com
}

\begin{abstract}
The purpose of this research is to know the internal and external environment that affects the development of agroindustrial business and syrup Parijoto and formulate alternative strategies for business development of agroindustrial syrup Parijoto in Colo-Village district Dawe Kudu Regency. The methods used in location selection and sampling of respondents are purposive sampling. Total number of 24 respondents. Data analysis methods consist of first data analysis using Internal Factors Evaluation (IFE) and External Factors Evaluation (EFE), while second data analysis using SWOT matrix. The Total value of Matrik IFE is 3.11, this shows that the strength of the entrepreneurs of parijoto syrup is able to overcome the weakness. The Total value of Efe's matrix is 3.27, which shows that the opportunity of the Parijoto syrup entrepreneur is able to cope with the threat. Based on the construction of the matrix IE known that the business of Parijoto syrup in Colo village is in the area of cell I is growing and building, means the business of Parijoto syrup has the opportunity to continue to grow and continue to build. The strategies suitable for this area are market penetration, market development, and product development. The right alternative strategy for this endeavor is to use the power to capitalize on existing opportunities. Personal capital, quality produced products, have a PIRT and a halal label so that employers can run and improve its production business.
\end{abstract}

Keywords: development strategy, Parijoto syrup, SWOT analysis.

\begin{abstract}
ABSTRAK
Desa Colo Kecamatan Dawe Kabupaten Kudus memiliki potensi besar untuk pengembangan dalam sektor agroindustri olahan buah parijoto yang menghasilkan sirup parijoto. Tujuan penelitian ini adalah untuk mengetahui lingkungan internal dan eksternal yang mempengaruhi pengembangan usaha agroindustri sirup parijoto serta merumuskan alternatif strategi pengembangan usaha agroindustri sirup parijoto di Desa Colo Kecamatan Dawe Kabupaten Kudus. Metode dasar yang digunakan adalah deskriptif kualitatif. Metode yang digunakan dalam pemilihan lokasi dan pengambilan sampel responden adalah purposive sampling. Jumlah responden sebanyak 24 responden. Metode analisis data terdiri dari analisis data pertama dengan menggunakan matrik Internal Factors Evaluation (IFE) dan External Factors Evaluation (EFE) sedangkan analisis data kedua menggunakan matriks SWOT. Total nilai dari Matrik IFE yaitu sebesar 3,11, hal ini menunjukan bahwa kekuatan yang dimiliki pengusaha sirup parijoto mampu mengatasi kelemahan. Total nilai dari matrik EFE yaitu sebesar 3,27, hal ini menunjukan bahwa peluang yang dimiliki pengusaha sirup parijoto mampu mengatasi ancaman. Berdasarkan pemetakan matrik IE diketahui bahwa usaha sirup parijoto di Desa Colo berada di daerah sel I adalah tumbuh dan membangun, berarti usaha sirup parijoto memiliki peluang untuk terus tumbuh dan terus membangun. Strategi
\end{abstract}




\section{AGRINIECA}

JURNAL ILMIAH AGRINECA

ISSN : 2721-074X (Online) - 2301-6698 (Print)

Available on : http://ejournal.utp.ac.id/index.php/AFP/index

This is Under CC BY SA Licence

yang cocok untuk daerah ini adalah penetrasi pasar, pengembangan pasar, dan pengembangan produk. Strategi alternatif yang tepat untuk usaha ini adalah menggunakan kekuatan untuk memanfaatkan peluang yang ada. Modal milik pribadi, produk yang dihasilkan berkualitas, memiliki PIRT dan label halal sehingga pengusaha dapat menjalankan dan meningkatkan usaha produksinya.

Kata Kunci : Strategi Pengembangan, Sirup Parijoto, Analisis SWOT.

\section{PENDAHULUAN}

Indonesia merupakan negara agraris yang memiliki potensi beragam dalam bidang pertanian. Pertanian merupakan sektor penting dalam pertumbuhan ekonomi nasional. Hal ini disebabkan sebagian besar penduduk Indonesia bermata pencaharian sebagai petani. Sektor pertanian menduduki posisi strategis yang dikaitkan dengan fungsinya untuk mencapai beberapa tujuan antara lain untuk mencapai swasembada pangan, meningkatkan sumber devisa negara, dan menaikan pendapatan petani yang merupakan lapisan terbesar masyarakat.

Industrialisasi pertanian dikenal dengan nama agroindustri, dimana agroindustri dapat menjadi salah satu pilihan strategis dalam upaya menghadapi masalah peningkatan perekonomian masyarakat di pedesaan serta mampu menciptakn kesempatan kerja bagi masyarakatdi pedesaan. Sektor industi pertanian merupakan salah satu sistem pengolahan secara terpadu antar sektor pertanian dengan sektor agroindustri guna mendapatkan nilai tambah dari hasil pertanian (Saragih, 2004).

Pengembangan agroindustri secara tidak langsung dapat membantu perekonomian para petani sebagai penyedia bahan baku untuk industri, serta dapat menambah pendapatan bagi para pengusaha industri olahan makanan dan minuman. Kabupaten Kudus tepatnya di Desa Colo Kecamatan Dawe memiliki potensi besar yang untuk dikembangkan dalam sektor agroindustri olahan buah parijoto yang menghasilkan olahan sirup parijoto, kripik parijoto, permen parijoto dan usaha jenis lainya. Mengingat Desa Colo merupakan sentra budidaya tanaman parijoto.

Pengembangan agroindustri sirup parijoto di Desa Colo Kecamatan Dawe Kabupaten
Kudus masih dihadapkan pada beberapa kendala seperti sulitnya mendapatkan bantuan modal, pemasaran yang masih terbatas di dalam dan di luar Kabupaten Kudus, teknologi yang masih manual, serta kurang adanya promosi. Hal ini menyebabkan kuantitas dan kontinyuitas produksi sirup parijoto masih rendah sehingga keuntungan yang diperoleh masih belum optimal maka perlu adanya strategi penegembangan usaha. Dimana dalam proses perkembangan sebuah usaha perlu diperhatikan lingkungan internal dan eksternalnya.

Penelitian ini bertujuan untuk meneliti beberapa rumusan masalah, antara lain mengetahui lingkung internal dan eksternal yang mempengaruhi pengembangan usaha agroindustri sirup parijoto di Desa Colo dan Merumuskan alternatif strategi pengembangan usaha agroindustri sirup parijoto di Desa Colo Kecamatan Dawe Kabupaten Kudus.

\section{METODE PENELITIAN}

Metode dasar yang digunakan dalam penelitian ini adalah metode deskriptif kualitatif. Penelitian deskriptif kualitatif adalah penelitian yang bermaksud untuk memahami fenomena tentang apa yang dialami oleh subyek penelitian, misalnya perilaku, persepsi, motivasi, tindakan, dan lain-lain secara holistik dan dengan cara deskripsi dalam bentuk katakata dan bahasa pada suatu konteks khusus yang alamiah dan dengan memanfaatkan berbagai metode alamiah (Moleong, 2007).

Penelitian ini dilakukan di Desa Colo Kecamatan Dawe Kabupaten Kudus. Tempat penelitian ini dipilih secara sengaja (purposive Sampling) dengan pertimbangan bahwa Desa Colo merupakan sentra sirup parijoto di Kabupaten Kudus, (Soeratno, 2003). Jumlah responden pada penelitian ini sebanyak 24 
responden terdiri dari 4 pengusaha, 10 konsumen, 5 distributor, 2 pemasok bahan baku, 1 perwakilan tokoh desa, 1 Dinas UMKM, 1 Dinas Industri Kabupaten Kudus.

Metode pengambilan sampel responden dengan menggunakan metode Purposive Sampling. Informasi kunci ditentukan dengan pertimbangan tertentu. Pertimbangan tersebut seperti orang tersebut dianggap paling tahu tentang informasi yang diharapkan atau orang tersebut merupakan orang yang berpengaruh sehingga memudahkan peneliti untuk menggali informasi dari obyek yang dibutuhkan (Sugiyono, 2006).

Menurut Rangkuti (2008), metode analisis data yang digunakan untuk menjawab penelitian ini adalah sebagai berikut :

1. Analisis faktor internal dan eksternal

Menganalisis faktor internal dan eksternal yang berpengaruh terhadap usaha agroindustri sirup parijoto dengan menggunakan matrik Internal Factors Evaluation (IFE) mengklasifikasi kekuatan dan kelemahan dan External Factors Evaluation (EFE) mengklasifikasikan peluang dan ancaman.

2. Analisis strategi pengembangan usaha agroindustry sirup parijoto
Menganalisis strategi pengembangan usaha agroindustri sirup parijoto dengan matiks SWOT. Analisis yang dilakukan untuk mengetahui alternatif strategi bisnis yang tepat diterapkan pada pengembangan agroindustri sirup parijoto yaitu menggunakan analisis SWOT. Adapun matrik analisis SWOT disusun berdasarkan deskripsi faktor-faktor internal dan eksternal yang kemudian masuk kedalam bentuk matrik SWOT yang menghasilkan empat alternatif strategi yaitu terdiri dari startegi SO, Stategi S-T, strategi W-O, dan Strategi W-T. Perumusan alternatef strategi dilakukan berdasarkan hasil dari penentuan posisi pada diagram analisis SWOT.

\section{HASIL DAN PEMBAHASAN}

\section{Identifikasi Faktor Internal}

Identifikasi faktor strategis internal merupakan tahapan menganalisis faktor-faktor yang terjadi didalam usaha sirup parijoto di Desa Colo Kecamatan Dawe Kabupaten Kudus yang meliputi kondisi keuangan (modal), manajemen, produksi, sumber daya manusia, teknologi, kualitas produk, labelisasi produk dan pemasaran.

Tabel 1. Identifikasi Faktor-Faktor Internal Usaha Sirup Parijoto di Desa Colo

\begin{tabular}{|c|c|c|c|}
\hline No & Faktor Internal & Kekuatan & Kelemahan \\
\hline 1. & Kondisi Keuangan (modal) & - Modal usaha milik pribadi & - Modal usaha terbatas \\
\hline 2. & Manajemen & & $\begin{array}{l}\text { - Tidak melakukan pembukuan } \\
\text { usaha }\end{array}$ \\
\hline 3. & Produksi & & $\begin{array}{l}\text { - Bahan baku tidak selalu } \\
\text { tersedia }\end{array}$ \\
\hline 4. & Sumber daya manusia & & - Membutuhkan keahlian khusus \\
\hline 5. & Teknologi & - Memiliki alat tepat guna & \\
\hline 7. & Kualitas produk & $\begin{array}{l}\text { - Produk berkualitas } \\
\text { - Produk tahan lama }\end{array}$ & \\
\hline 8. & Labelisasi produk & - Memiliki PIRT dan label halal & \\
\hline 9. & Pemasaran & $\begin{array}{l}\text { - Saluran pemasaran pendek } \\
\text { - Sudah melakukan promosi } \\
\text { - Pemasaran sudah sampai luar kota }\end{array}$ & \\
\hline
\end{tabular}


Berdasarkan Tabel 1 didapatlah beberapa faktor kekuatan dan kelemahan yang kemudian dilakukan penghitungan setiap faktor ke dalam matrik IFE.

Tabel 2. Rekapitulasi Faktor Internal Terbobot Matrik IFE

\begin{tabular}{llccc}
\hline No & Faktor-Faktor Internal Strategis & Bobot & Rating & $\begin{array}{c}\text { Bobot X } \\
\text { Rating }\end{array}$ \\
\hline$\quad$ Kekuatan & & & \\
1 & Modal usaha milik pribadi & 0,10 & 4 & 0,4 \\
2 & Memiliki alat tepat guna & 0,09 & 3 & 0,27 \\
3 & Produk yang diproduksi berkualitas & 0,10 & 4 & 0,4 \\
4 & Produk tahan lama & 0,10 & 4 & 0,4 \\
5 & Memiliki PIRT dan label halal & 0,09 & 3 & 0,27 \\
6 & Saluran pemasaran pendek & 0,10 & 3 & 0,3 \\
7 & Sudah melakukan promosi & 0,10 & 4 & 0,4 \\
8 & Pemasaran sudah sampai luar kota & 0,08 & 3 & 0,24 \\
& $\quad$ Kelemahan & & & 0,12 \\
1 & Modal usaha terbatas & 0,06 & 2 & 0,05 \\
2 & Tidak melakukan pembukuan & 0,05 & 1 & 0,12 \\
3 & Bahan baku tidak selalu tersedia & 0,06 & 2 & 0,14 \\
4 & Membutuhkan keahlian khusus & Total & 0,07 & $\mathbf{3 , 1 1}$ \\
\hline
\end{tabular}

Sumber : Analisis Data Primer, 2019

Berdasarkan Tabel 2 didapat skor tertinggi pada faktor kekuatan adalah modal usaha milik pribadi, produk yang diproduksi berkualitas, produk tahan lama dan sudah melakukan promosi dengan skor 0,4. Skor terendah pada faktor kekuatan adalah pemasaran sudah sampai luar kota dengan skor 0,24. Pada faktor kelemahan skor tertinggi terdapat pada faktor membutuhkan keahlian khusus dengan skor 0,14. Skor terendah pada faktor kelemahan yaitu modal usaha terbatas dan bahan baku tidak selalu tersedia dengan skor 0,12 , dari semua skor faktor internal strategis dijumlahkan dan mendapatkan total skor matrik IFE sebesar 3,11. Hal ini berarti kondisi internal usaha sirup parijoto di Desa
Colo berada pada daerah kuat, yang berarti bahwa kekuatan yang dimiliki pengusaha sirup parijoto di Desa Colo dapat mengatasasi kelemahan dengan baik. Hal ini sejalan dengan penelitian Siti Nur Latifah yang hasil penelitian menunjukkan kekuatan yang dimiliki mampu mengatasi kelemahan. (Latifah. SN 2018)

\section{Identifikasi Faktor Eksternal}

Identifikasi faktor eksternal merupakan tahapan menganalisis faktor-faktor yang terjadi di luar usaha pengusaha sirup parijoto di Desa Colo Kecamatan Dawe Kabupaten Kudus yang meliputi kondisi perekonomian, persaingan, konsumen, distributor atau reseller, merek dagang, pemasok bahan baku dan pemerintah.

Tabel 3. Identifikasi Faktor-Faktor Eksternal Usaha Sirup Parijoto di Desa Colo

\begin{tabular}{cccc}
\hline No & \multicolumn{1}{c}{ Fakor Eksternal } & \multicolumn{1}{c}{ Peluang } & Ancaman \\
\hline 1. & Kondisi Perekonomian & - Peminjaman modal mudah & $-\begin{array}{l}\text { Harga produk tetap saat } \\
\text { harga bahan baku naik }\end{array}$ \\
2. & Persaingan & - Pengusaha banyak di Desa Colo &
\end{tabular}


JURNAL ILMIAH AGRINECA

ISSN : 2721-074X (Online) - 2301-6698 (Print)

Available on : http://ejournal.utp.ac.id/index.php/AFP/index

This is Under CC BY SA Licence

3. Konsumen

4. Distributor/reseller

5. Merek Dagang

6. Pemasok Bahan Baku

7. Pemerintah
- Memiliki konsumen tetap

- Permintaan juga dipengaruhi hari

$$
\begin{aligned}
& \text { - Memiliki Distributor dan Reseller } \\
& \text { tetap } \\
& \text { - Produk sudah terkenal } \\
& \text { - Dukungan penjual bahan baku } \\
& \text { - Adanya dukungan pemerintah }
\end{aligned}
$$

Sumber : Analisis Data Primer, 2019

Berdasarkan Tabel 3 didapatlah beberapa faktor

\begin{tabular}{|c|c|c|c|c|}
\hline No & Faktor Eksternal Strategis & Bobot & Rating & Bobot X Rating \\
\hline \multicolumn{5}{|c|}{ Peluang } \\
\hline 1. & Peminjaman modal mudah & 0,12 & 4 & 0,48 \\
\hline 2. & Pengusaha banyak di Desa Colo & 0,10 & 3 & 0,3 \\
\hline 3. & Memiliki konsumen tetap & 0,13 & 4 & 0,52 \\
\hline 4. & Permintaan juga dipengaruhi hari & 0,10 & 3 & 0,3 \\
\hline 5. & Memiliki distributor dan reseller tetap & 0,11 & 3 & 0,33 \\
\hline 6. & Produk sudah terkenal & 0,10 & 3 & 0,3 \\
\hline 7. & Dukungan penjual bahan baku & 0,10 & 3 & 0,3 \\
\hline 8. & Adanya dukungan pemerintah & 0,13 & 4 & 0,52 \\
\hline \multicolumn{5}{|c|}{ Ancaman } \\
\hline 1. & Harga produk tetap saat harga bahan baku naik & 0,06 & 2 & 0,12 \\
\hline 2. & Harga produk konstan & 0,05 & 2 & 0,1 \\
\hline & Total & 1 & & 3,27 \\
\hline
\end{tabular}
peluang dan faktor ancaman yang kemudian dilakukan penghitungan setiap faktor kedalam matrik EFE.

Tabel 4. Rekapitulasi Faktor Eksternal Terbobot Matrik EFE

\section{Sumber: Analisis Data Primer, 2018}

Berdasarkan Tabel 4 di dapat skor tertinggi pada faktor peluang adalah memiliki konsumen tetap dan adanya dukungan pemerintah dengan skor 0,52. Skor terendah pada faktor peluang yaitu pengusaha banyak di Desa Colo, permintaan dipengaruhi hari dan dukungan penjual bahan baku dengan skor 0,3. Faktor ancaman skor tertinggi pada faktor harga produk constant dengan skor 0,1 . Skor terendah pada faktor ancaman harga produk tetap saat hrga bahan baku naik dengan skor 0,12 . Total skor matrik EFE sebesar 3,27. Hal ini berarti kondisi eksternal usaha sirup parijoto di Desa
Colo berada pada daerah kuat, yang berarti bahwa peluang yang dimiliki pengusaha sirup parijoto di Desa Colo dapat mengatasasi ancaman dengan baik. Hal ini sejalan dengan penelitian Siti Nur Latifah hasil penelitian menunjukkan peluang mampu mengatasi acaman (Latifah, SN 2018)

Setelah perhitungan setiap faktor kedalam matrik EFE kemudian dilakukan identifikasi faktor strategis eksternal yang berupa faktor peluang dan ancaman dari usaha sirup parijoto di Desa Colo. 


\section{JURNAL ILMIAH AGRINECA}

ISSN : 2721-074X (Online) - 2301-6698 (Print)

Available on : http://ejournal.utp.ac.id/index.php/AFP/index

This is Under CC BY SA Licence

Matrik IE

\begin{tabular}{|c|c|c|c|c|}
\hline & & Kuat & & Lemah \\
\hline & & $3,0-4,0$ & $\begin{array}{l}\text { Rata-rata } \\
2,0-2,99\end{array}$ & $1,0-1,99$ \\
\hline & $\begin{array}{c}\text { Kuat } \\
3,0-4,0\end{array}$ & $\begin{array}{c}\text { I } \\
\text { Tumbuh dan } \\
\text { Membangun }\end{array}$ & $\begin{array}{c}\text { II } \\
\text { Tumbuh dan } \\
\text { Membangun }\end{array}$ & $\begin{array}{c}\text { III } \\
\text { Pertahankan dan } \\
\text { Pelihara }\end{array}$ \\
\hline $\begin{array}{l}\text { Total } \\
\text { Skor } \\
\text { EFE } \\
3.27\end{array}$ & $\begin{array}{l}\text { Rata-rata } \\
2,0-2,99\end{array}$ & $\begin{array}{c}\text { IV } \\
\text { Tumbuh dan } \\
\text { Membangun }\end{array}$ & $\begin{array}{c}\mathrm{V} \\
\text { Pertahankan dan } \\
\text { Pelihara }\end{array}$ & $\begin{array}{c}\text { VI } \\
\text { Panen dan } \\
\text { Divestasi }\end{array}$ \\
\hline & $\begin{array}{l}\text { Lemah } \\
1,0-1,99\end{array}$ & $\begin{array}{c}\text { VII } \\
\text { Pertahankan dan } \\
\text { Pelihara }\end{array}$ & $\begin{array}{c}\text { VIII } \\
\text { Panen dan } \\
\text { Divestasi }\end{array}$ & $\begin{array}{c}\text { IX } \\
\text { Panen dan } \\
\text { Divestasi }\end{array}$ \\
\hline
\end{tabular}

Gambar 1. Total Matrik IE

Total Skor IFE 3,11
2. Pengembangan pasar perlu dilakukan untuk meningkatkan dan mencari kelompok baru untuk memperluas lokasi pemasaran. Berdasarkan penelitian pemasaran agroindustri sirup parijoto di Desa Colo hanya terbatas di pasar lokal saja yaitu pemasaran masih dilingkungan provinsi Jawa Tengah. Langkah pengembangan pemasaran ini dapat dilakukan dengan melakukan promosi.

3. Pengembangan produk perlu dilakukan untuk melakukan perbaikan produk pada sisi kemasan produk sirup parijoto dibuat semenarik mungkin dan mengganti yang sudah ada selama ini, atau mengembangkan produk yang baru, sehingga dapat meningkatkan penjualan perusahaan. 
JURNAL ILMIAH AGRINECA

ISSN : 2721-074X (Online) - 2301-6698 (Print)

Available on : http://ejournal.utp.ac.id/index.php/AFP/index

This is Under CC BY SA Licence

Tabel 5. Alternatif Strategi Pengembangan Usaha Sirup parijoto (Matrik SWOT)

\begin{tabular}{|c|c|c|}
\hline EFE & \begin{tabular}{ll} 
& \multicolumn{1}{c}{ Kekuatan (S) } \\
1. & Modal usaha milik pribadi \\
2. & Memiliki alat tepat guna \\
3. & Produk yang di produksi berkualitas \\
4. & Produk tahan lama \\
5. & Memiliki PIRT dan label halal \\
6. & Saluran pemasaran pendek \\
7. & Sudah melakukan promosi \\
8. & Pemasaran sudah sampai luar kota
\end{tabular} & \begin{tabular}{ll} 
& \multicolumn{1}{c}{ Kelemahan (W) } \\
1. & Modal usaha terbatas \\
2. & Tidak melakukan pembukuan \\
3. & Bahan baku tidak selalu tersedia \\
4. & Membutuhkan keahlian khusus
\end{tabular} \\
\hline \begin{tabular}{ll}
\multicolumn{1}{c}{ Peluang $(\mathbf{O})$} \\
1. Peminjaman modal mudah \\
2. Pengusaha banyak di Desa \\
Colo \\
3. Memiliki konsumen tetap \\
4. Permintaan juga \\
dipengaruhi hari \\
5. Memiliki distributor dan \\
reseller tetap \\
6. Produk sudah terkenal \\
7. $\begin{array}{l}\text { Dukungan penjual bahan } \\
\text { baku }\end{array}$ \\
8. Dukungan pemerintah \\
daearah.
\end{tabular} & $\begin{array}{l}\text { Strategi S-O } \\
\text { 1. Pengusaha dapat menjalankan dan } \\
\text { meningkatkan usaha produksinya } \\
\text { mengingat produk sudah terkenal serta } \\
\text { memiliki ijin PIRT, label halal dan } \\
\text { menggunakan alat tepat guna yang dimiliki } \\
\text { sehingga dapat memenuhi permintaan } \\
\text { konsumen, distributor, reseller yang } \\
\text { dimilikinya serta dapat memenuhi } \\
\text { permintaan pada hari-hari tertentu. } \\
\text { (O6, S5, S2, O3, O5, O4) } \\
\text { Mengadakan pelatihan bagi pengusaha } \\
\text { dengan melibatkan pemerintah daerah } \\
\text { terkait untuk mengadakan sosialisasi } \\
\text { tentang pentingnya penggunaan alat tepat } \\
\text { guna pada proses produksi sehingga produk } \\
\text { yang dihasilkan berkualitas. } \\
\text { (O8, S2, S3) }\end{array}$ & $\begin{array}{l}\text { Strategi W-O } \\
\text { 1. Pengusaha perlu meminjam modal } \\
\text { untuk mengatasi masalah modal } \\
\text { yang terbatas serta memulai untuk } \\
\text { melakukan pembukuan usaha. } \\
\text { (O1, W1, W2) } \\
\text { 2. Perlu adanya peran pihak } \\
\text { pemerintah terkait untuk } \\
\text { memberikan pelatihan kepada } \\
\text { petani parijoto supaya budidaya } \\
\text { parijoto bisa maksimal dan dapat } \\
\text { memenuhi kebutuhan bahan baku } \\
\text { produksi sehingga produsen bisa } \\
\text { berproduksi setiap harinya tanpa } \\
\text { ada kendala dalam masalah bahan } \\
\text { baku yang tidak selalu tersedia. } \\
\text { (O8, O7, W3) }\end{array}$ \\
\hline $\begin{array}{l}\text { Ancaman (T) } \\
\text { 1. Harga produk tetap saat } \\
\text { harga bahan baku naik. } \\
\text { 2. Harga produk konstan. }\end{array}$ & $\begin{array}{l}\text { Strategi S-T } \\
\text { 1. Harga produk konstan dapat dapat diatasi } \\
\text { dengan cara maksimal penggunaan alat } \\
\text { tepat guna sehingga produk yang dihasilkan } \\
\text { mutunya bisa maksimal dan jangkauan } \\
\text { pemasaran bisa lebih luas. } \\
\text { (T2, S2) }\end{array}$ & $\begin{array}{l}\text { Strategi W-T } \\
\text { 1. Pemasok bahan baku harus } \\
\text { memaksimalkan proses budidaya } \\
\text { parijoto sehingga bahan baku selalu } \\
\text { tersedia agar tidak terjadi kenaikan } \\
\text { pada harga produk sehingga harga } \\
\text { jual produk tetap stabil. } \\
\text { (W3, T1) }\end{array}$ \\
\hline
\end{tabular}

Sumber : Analisis Data Primer, 2019

Berdasarkan Tabel 5 posisi strategi pengembangan usaha sirup parijoto di Desa Colo difokuskan bagi pengembangan usaha yaitu menggunakan strategi S-O strategi yang menggunakan kekuatan internal usaha untuk memanfaatkan peluang ekesternal, sehingga strategi yang relevan untuk dilaksanakan bagi pengembangan usaha sirup parijoto di Desa Colo antara lain Pengusaha dapat menjalankan dan meningkatkan usaha produksi sirup parijoto mengingat produk sirup parijoto sudah terkenal serta memiliki ijin PIRT,berlabel halal dan diharapkan bagi pengusaha untuk menggunakan alat tepat guna yang dimiliki secara maksimal sehingga dapat memenuhi permintaan konsumen, distributor, reseller yang dimilikinya serta dapat memenuhi permintaan pada hari-hari tertentu. 


\section{AGRINECA}

JURNAL ILMIAH AGRINECA

ISSN : 2721-074X (Online) - 2301-6698 (Print)

Available on : http://ejournal.utp.ac.id/index.php/AFP/index

This is Under CC BY SA Licence

\section{KESIMPULAN DAN SARAN}

Faktor-faktor internal dan eksternal yang ada dalam pengembangan usaha agroindustri sirup parijoto di Desa Colo Kecamatan Dawe Kabupaten Kudus adalah sebagai berikut :

a. Kekuatan : modal usaha milik pribadi, memiliki alat tepat guna, produk berkualitas dan tahan lama, memiliki ijin PIRT dan berlabel halal, sudah melakukan promosi, pemasaran sudah sampai luar kota dan saluran pemasran pendek

b. Kelemahan : modal usaha yang terbatas, tidak melakukan pembukuan usaha, bahan baku yang tidak selalu tersedia dan mebutuhkan keahlian khusus dalam produksi sirup parijoto.

c. Peluang : peminjaman modal mudah, memiliki konsumen, distributor dan reseller tetap, permintaan juga di pengaruhi harihari tertentu, produk sudah terkenal, bermitra dengan penjaul bahan baku dan adanya dukungan dari perintah daerah.

d. Ancaman : harga produk tetap saat terjadi kenaikan harga bahan baku dan harga produk konstant

Alternatif strategi yang dapat diterapkan dalam pengembangan usaha agroindustri sirup parijoto di Desa Colo Kecamatan Dawe Kabupaten Kudus adalah

a. Strategi S-O

1. Pengusaha harus benar-benar menggunakan alat tepat guna secara maksimal yang mana produk sirup parijoto sudah terkenal sudah memiliki ijin PIRT dan berlabel halal sehingga sudah dapat kepercayaan dari konsumen dan mampu untuk memenuhi permintaan peminat produk sirup parijoto pada setiap harinya.

2. Menggunaan alat tepat guna dapat memberikan nilai tamabah produk, jaminan mutu dan kualitas pada produk lebih baik lagi terutama pada sisi keawetan produk dan mempertahankan kualitas produk hingga sampai di tangan konsumen.

b. Strategi W-O
1. Pengusaha perlu meminjam modal untuk mengatasi masalah modal yang terbatas serta memulai untuk melakukan pembukuan usahaya.

Perlu adanya peran pihak pemerintah terkait untuk memberikan pelatihan dan penyuluhan kepada petani parijoto supaya budidaya parijoto bisa maksimal dan dapat memenuhi kebutuhan bahan baku produksi sehingga produsen bisa berproduksi setiap harinya tanpa ada kendala dalam masalah bahan baku yang tidak selalu tersedia.

\section{c. Strategi S-T}

Dengan kepemilikan alat tepat guna serta memiliki PIRT dan label halal pengusaha dapat mengatasi Harga produk yang konstan terutama pada saat terjadi inflasi bahan baku produksi.

d. Strategi W-T

Pengusaha diharapkan berani untuk meminjam modal demi kelangsungan produksinya dan pihak pemasok bahan baku supaya bisa memaksimalkan proses budidaya parijoto sehingga bahan baku selalu tersedia agar tidak terjadi kenaikan pada harga produk sehingga harga jual produk tetap stabil.

Pengusaha sirup parijoto di Desa Colo hendaknya melakukan pembukuan pada usahanya sehingga dapat digunakan untuk mengetahui perkembangan usaha dan meningkatkan usaha. Pengusaha sirup parijoto di Desa Colo hendaknya menggunakan alat tepat guna dengan maksimal yang mana produk sirup parijoto sudah terkenal sudah memiliki ijin PIRT dan berlabel halal sehingga sudah dapat kepercayaan dari konsumen dan mampu untuk memenuhi permintaan peminat produk sirup parijoto pada setiap harinya.

Bagi petani parijto hendaknya melakukan pengembangan budidaya tanaman parijoto tidak hanya di gunung muria, sebaiknya perlu dikembangkan di media tanam lainya seperti polybag, pot, screen house. Supaya tanaman parijoto mendapatkan perlakuan khusus, 
sehingga buah parijoto bisa berbuah secara maksimal dan mampu untuk memenuhi kebutuhan produsen sirup parijto. Peran Perangkat desa sebagai lingkup pemerintahan terkecil sebaiknya menyediakan tempat atau pusat untuk memasarkan produk sirup parijoto di Desa Colo.

Peran pemerintah daerah Kabupaten Kudus melalui dinas UMKM dan dinas industri

\section{DAFTAR PUSTAKA}

Kotler dan K.L. Keller. 2009. Manajemen Pemasaran, Edisi Keduabelas. Jakarta: Erlangga.

Latifah, SN. 2018. Strategi Pengembangan Agroindustri Tumpi Kacang Hijau di Dusun Karangbolo Desa Lerep Kecamatan Ungaran Barat Kabupaten Semarang. Skripsi, Universitas Wahid Hasyim, Semarang.

Moleong, L. 2007. Metode Penelitian Kualitatif. Bandung: Remaja Rosdakarya.

Rangkuti, F. 2002. Analisis SWOT Teknik Membedah Kasus Bisnis. Jakarta: PT Gramedia Pustaka Utama.

Rangkuti, F. 2009. Analisis SWOT Teknik Membedah Kasus Bisnis. Edisi Keenam Belas, PT. Jakarta: Gramedia Pustaka Utama.

Saragih, B. 2004. Membangun pertanian dalam prospektif agrobisnis dalam ruang. Jakarta: Erlangga.

Sugiyono, 2006. Metode Penelitian Bisnis. Bandung: Pusat Bahasa Depdiknas.

Soeratno, A. L. 2003.Metodologi Penelitian Untuk Ekonomi dan Bisnis. Jogjakarta: UPP AMP YKPN. sebagai fasilitator pengembangan usaha di Desa Colo sangat dibutuhkan. Pemerintah dapat memberikan bantuan berupa penyediaan koprasi modal ataupun koprasi bahan baku produksi untuk mempermudah para pengusaha jika terjadi keterbatasan modal pada pengusaha sehingga mampu meningkatkan produktivitasnya. 